\title{
繰返し力を受ける鋼構造材の履歴特性
}

建築架構の非線型振動解析に当り、建物各囯の復元力 特性として

- Elasto-Plastic Model

- Baushinger 效果を入れた Positive bi-linear 型の Jenkine Model

・部材軸力が卓越する場合の Negative bi-linear 型

- Clamped Connection 注対する Slip Model

等の抽象的な模型が想定されているが、いずれる可成り 直観的なもので充分な論拠を有寸るとは言い難い。事実 既往の実験的研究としては

鋲・溶接継手を刘象とする棚橋博士の研究、釗継手に 就いての金多博士の実験や、R.C 構造物飞関する武藤研 究室、T.H. Pian 等の一連の研究、実大架構に対する竹 山・後藤雨博士等の 2,3 の水平加力実験等が数兄られ るに過ぎない。以下に鋼構造物の弾塑性挙動を追究した 筆者等の実験資料上り、正負繰返し力下の復元力特性に ついての結論を導き取り㢞める次第でめる。

1. 履歴曲線の概形 供試体詳細の如何に関係なく、 単材及び溶接々合部の履歴 loop 江単純載荷曲線を基隼 とする紡鍍型をとり、鋲・ボルトによる接手部では slip 現象が著しく逆S字型を示す。

紡銼型の loop は単純加力時の荷重一変 形曲線より推定して大過なく、特にロール 材のそれは計算曲線より得られるものと近 似する。勾配は正負加力時とも注ぼ好女勾 配に等しく、荷重 (変形) 振门が増せぼ僅 そ緩くなる。溶接材では元応力の影響が塑 性曲線への早期移行となって現れ、又歪硬 化現象が不鮮明になりがちである。

逆 S 字型例の履歴曲線は複雑で、単純載 荷・片振り加力時曲線との関連性は稀薄で ある。

2. 同上安定性 $30 \sim 300 \mathrm{~mm} / \mathrm{min}$ の実験範围内で、 履釈曲線の概形に及ぼす変形速度の影響恃無視出来る。

R.E. Mc Carthy の Portal Frame に関する片振り 加力実験では破壊荷重に近い所の繰返しで変形量の不安 定な事を指摘しているが、筆者等の実験では紡鍾型 loop は荷重振巾の大小沟らず 2,3 cycle 目より定常化して $10 \mathrm{c}$ 程度では変りないが、逆 $\mathrm{S}$ 字型の特にボルト継手例 の loop 概形は荷重振门が増せば可成り不安定である。

3. 塑性流動性能 Web Pl. Panel Pl. の剪断降伏す

\section{正会員五十嵐定 義*}

るものには 15 を越劣る回転容量を期待出来るが、曲げ 応力度の卓越する場合は 10 前後、この值は軸力の割合 の增大に伴って 5 乃至 6 以下に減ずる。従って鞄性率の 限界を精々 6 程度に抑光るのが望をしい。

4. 破壊過程 板の剪断降伏、Flange, Web Pl. の局 部座屈例で注最大荷重点通過後の耐力の低下は極めて緩: 慢だが、柱梁隅角部・曲怗材の横座屈例の荷重一変形曲: 線は急公配で低落する。この傾向は H.M. Nelson 等の 実験結果と一致する所ではあるが、異った実験結果も。 2，3 報告されているので尚検討の余地がある。

実際の構造物に活用される H.T. ボル卜接合部に対し. ては slip 現象を含む複雑な特性が予想されるが、これ については充分な資料を持たない。又 Residual Strees. によって履歴曲線の線型領域が狭まり降伏点を低下した 形で徐々飞塑性域に移行する現象の定量的な处理 合後 の問題である。更に、高次の不静定架構では塑性関節が 順次発生して行く過程によって履歴曲線の弾塑性部分の 形状を異にするから、以上飞記した単枸・単一接合部に ついての実験結果のみで架構の一般的な復元力特性を諭 じ儘し得ない。然し斯様な問題点を一応考慮外飞置けば 鋼構造材に生ずる塑性関節の耐力は、動的加力時の僅

\footnotetext{
*九州大学助教授 工博
} 